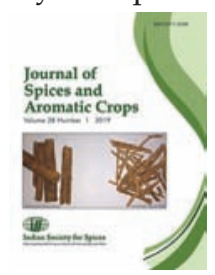

\title{
Trade competitiveness and export performance of Indian cardamom
}

\author{
L Thomas*, P Rajeev \& P C Sanil \\ ICAR-Indian Institute of Spices Research, Kozhikode-673 012, Kerala. \\ *E-mail:lijo.iari@gmail.com
}

Received 03 June 2019; Revised 27 June 2019; Accepted 28 June 2019

\begin{abstract}
India is one of the major producers and consumer of cardamom. The export performance of cardamom has witnessed several changes over the past few decades. This paper analyses the trends and performance of cardamom commodity from India. Using secondary data from the Spices Board and the Ministry of Commerce along with international trade data from the United Nations International Trade Statistics Database, the trend in the domestic production and export markets is clearly drawn out. The changes in Revealed Comparative Advantage in cardamom exports over the years is used to study the level and changes in the export competitiveness of the commodity. The study identifies a revival in export competiveness in the recent years along with an increase in the share of global cardamom exports. The highly concentrated production of cardamom, the preference for Indian cardamom in Middle East economies and the revival of export competitiveness can benefit the Indian cardamom producers. The study argues for strengthening research investments in cardamom for sustaining and enhancing the benefits from cardamom exports from the country.
\end{abstract}

Keywords: cardamom, exports, revealed comparative advantage, trade

\section{Introduction}

Spices have played an important role in shaping the history of agricultural trade and it continues to play a significant role in the current international trade scenario. Cardamom, known as the queen of spices, is cultivated in nearly one lakh hectares (Spices Board 2018). The cardamom output during 2017-18 was twenty six thousand tonnes. The significant gains in price of small cardamom in recent months has shifted the focus on this crop. The average small cardamom auction price realized during the first fortnight of May 2019 was $2469 \mathrm{~kg}^{-1}$ at cardamom auction centre in Kerala whereas the all India average small cardamom auction price for ungraded cardamom during 2017-18 was Rs 955 $\mathrm{kg}^{-1}$. Though cardamom has been a traditional spice crop in India with steady gains in production and productivity, the export competitiveness of the crop has shown considerable fluctuations (Nagoor 2010). The fluctuations in export competitiveness were more associated with international competition. In case 
of small cardamom cultivation in Kerala, the economic viability of the crop has also seen significant fluctuations (Varghese 2007). India Guatemala and Indonesia are the major supply sources of cardamom in the international market with a share of more than $85 \%$ of the global trade in the commodity (USDA 2014). The Indian cardamom grades traded in the international market often command an instant appeal among worldwide (Spices Board 2015).

In India, two types of cardamom are grown; small cardamom (Elettaria cardamomum Maton) and large cardamom (Amomum subulatum Roxb.) (Nair 2011). The production of small cardamom is confined to the southern states while large cardamom is grown mainly in Sikkim and West Bengal. Kerala accounts for $87 \%$ of the area under small cardamom followed by Karnataka (7\%). On the other hand, more than $82 \%$ of the large cardamom is produced from Sikkim in India. The share of small cardamom in total area under cardamom was $72 \%$ during the biennium ending 2017-18.

A significant share of the cardamom produced in the country originates from small holdings and hence the trade and market performance of the crop is important for the livelihood security of the primary producers of the commodity. Being a globally traded commodity, the trade competitiveness of the cardamom is a key factor in shaping the crop economy in terms of competitiveness and guiding resource allocation decisions by farmers. The advent of systematic auction process in cardamom vide Cardamom (Licensing and Marketing) Amendment Rules, 2014 (Government of India 2014) was intended to address the domestic institutional constraints leading to price instability in produce. Apart from price instability which affects farm business income for cardamom producers (Anoopkumar 2014), the export demand for cardamom can also significantly influence the cardamom economy. The analysis of the trade performance of the cardamom sector is important to identify critical constraints in production environment and trade. In this paper, the trade performance of cardamom is examined in detail to bring out the key trends in performance and competitiveness of cardamom export from India.

\section{Materials and methods}

The secondary data on area, production, productivity of cardamom was obtained from the Spices Board and the Directorate of Economics and Statistics, Government of India. The annual data on export quantity, value and composition of exports were obtained from Export Import databank maintained by the Ministry of Commerce \& Industry, Government of India. To compute the revealed comparative advantage, apart from data on Indian cardamom trade and merchandise trade, international trade data was also required. This data was obtained from World Integrated Trade Solution database (WITS database) and United Nations International Trade Statistics Database (UN Comtrade). At the international level, the harmonised system for classification of traded goods (six digit codes) does not distinguish between small and large cardamom. Therefore for, the purpose of trade analysis we have aggregated the trade data for small and large cardamom. Two periods approximately spanning slightly over two decades each on either side of the liberalization drive in Indian economy was analysed.

\section{Growth rate, instability}

The compound annual growth rate was used to measure the growth in key parameters like area, production and productivity affecting domestic availability of cardamom in the country. The instability associated with cardamom area, production, yield, export quantity, value and unit value of export was estimated using the following index

Instability Index $=$ Standard deviation of natural logarithm $\left(\mathrm{X}_{\mathrm{t}+1} / \mathrm{X}_{\mathrm{t}}\right) \quad--$ (Eq. 1)

Where, $X_{t}$ refers to the parameter in the current year and $X_{t+1}$ denotes the value for the same parameter for the subsequent year. This index of instability is robust, unit free and measures deviations from the underlying trend. In the absence of deviations from the trend, the standard deviation would be zero since the ratio between $X_{t+1}$ and $X_{t}$ remains same (Chand \& Raju 2008).

\section{Revealed comparative advantage}

Among the several approaches used for assessing 
competitiveness of exports, the Revealed Comparative Advantage (RCA) index of Balassa (1965) is one of the most commonly employed methods. The competitiveness of cardamom exports from India was measured using Revealed Comparative Advantage (RCA). The RCA is now widely used as a measure of international trade specialisation. The RCA identifies the comparative advantage or disadvantage of a particular country with respect to another country or group of countries for a specific commodity. Among the several factors which can influence RCA, economic factors, trade structure, world demand scenario and trade specialization can be of immediate significance (Shinoj \& Mathur 2008). The measure also captures the intercountry differences in relative costs and other non-price factors which affects the relative advantage in trading of that commodity.

RCA and can be expressed as

$$
R C A=\frac{\left(x_{i j} / x_{i k}\right)}{\left(x_{n j} / X_{n k}\right)} \quad--(\text { Eq. 2) }
$$

Where, $X_{i j}=$ Exports of country ' $i$ ' of commodity ' $j$ '; $X_{i k}=$ Exports of country ' $i$ ' of a set of commodities ' $\mathrm{k}^{\prime} ; \mathrm{X}_{\mathrm{nj}}=$ Exports of a set of countries ' $n$ ' of commodities ' $j$ ' and $X_{n k}=$ Exports of a set of countries ' $\mathrm{n}$ ' of a set of commodities ' $\mathrm{k}$ '

In the present study, country ' $i$ ' refers to India, commodity ' $j$ ' refers to cardamom, set of commodities ' $\mathrm{k}$ ' refers to all commodities and set of counties ' $n$ ' refers to World. The value of index is greater than unity indicates an economy's international competitiveness. Since we are interested in the trends in India's export competitiveness, the movements in RCA would be sufficient to understand the changes in export competitiveness of Indian cardamom exports.

\section{Results and discussion}

\section{Trends in cardamom production in India}

Domestic production of cardamom increased by more than five times during the last four decades. Cardamom output, which was 3,600 tonnes during the triennium ending 1972-73 increased to 25,600 tonnes for the triennium ending 201718 (Fig. 1). The growth in output was mainly productivity driven with the area under cardamom remaining stagnant since 1990's. The cardamom yield has more than doubled during the last three decades from $103 \mathrm{~kg}$ per ha-1 during 1992-93 to $267 \mathrm{~kg} \mathrm{ha}^{-1}$ during 2017-18.

The compound annual growth rate (CAGR) and instability associated with area, production, yield and export quantity of cardamom highlights key trends in the crop (Table 1). The period I is from 1971-72 to 1993-94 and period II is from 1994-95 to 2017-18. The area under cardamom and output from the sector witnessed sharp deceleration in growth whereas the yield growth rates remained robust throughout the study period. The sustained yield growth rate resulted in the growth in cardamom production even with declining growth rates in production and area. The instability in production and yield has shown a decline in the second period. The lower instability in yield and production could be attributed to the spread of varieties with high yield potential. The ruling variety of small cardamom, Njallani, a farmer variety, has high root cation capacity leading to high yield levels under intensive management. The spread of such varieties along with intensive management practices based on increased use of plant protection chemicals were important factors in improving yield and addressing biotic stress factors (Murugan et al. 2011). The instability in export quantity has also declined significantly. Considering the trade potential and demand for cardamom, the crop is expected to retain commercial significance in coming years (Nair 2006).

\section{Global production scenario}

Global cardamom production during 2017 is estimated at 1,14,664 tonnes (FAOSTAT). Guatemala, India and Indonesia are the major cardamom producing countries in the world. These three countries contributed $85 \%$ of the total cardamom production in the world. This indicates a high degree of concentration in cardamom production at the global level. The major cardamom consuming countries are Middle Eastern Countries like Saudi Arabia and United Arab Emirates, countries of the European Union, United States, Pakistan and Japan. There has been a steady growth in the cardamom output in the major producing countries during the last five decades (Table 2). 


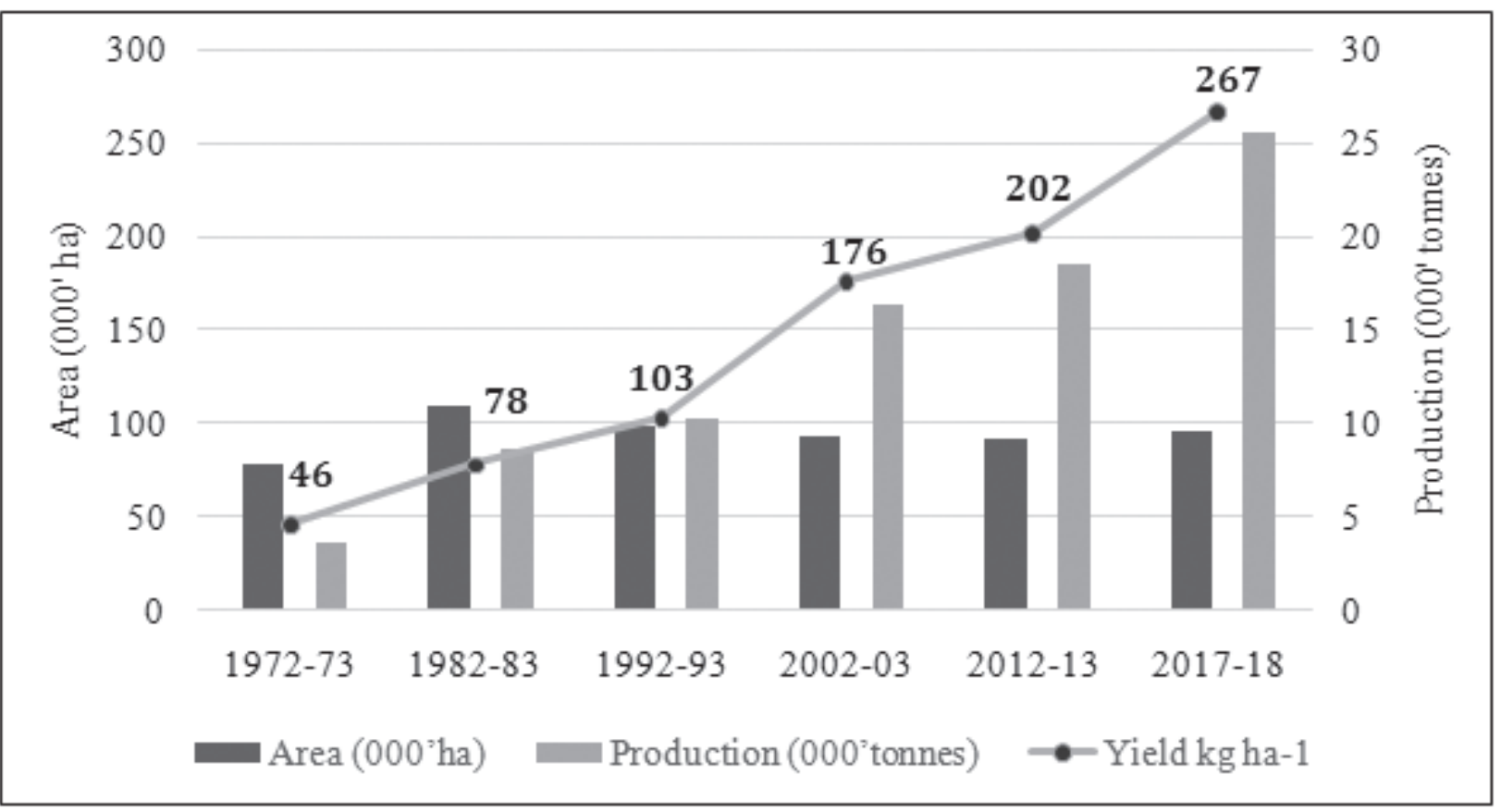

Fig. 1. Trends in area, production, and yield of cardamom

Though India and Guatemala have a similar share in total cardamom production, Guatemala exports significantly higher quantities of cardamom since the strong domestic consumption demand in India affects the exportable surplus. The domestic consumption of small cardamom, as measured by the difference between domestic production and exports, increased by $423 \%$ between $1990-91$ and $2004-05$ (Nair 2006) and further by $38 \%$ during the next

Table 1. Growth and instability in cardamom crop

\begin{tabular}{lcccccccc}
\hline \multirow{2}{*}{ Particulars } & \multicolumn{2}{c}{$1971-72$ to $1993-94$} & & \multicolumn{2}{c}{$1994-95$ to $2017-18$} & & \multicolumn{2}{c}{ Overall Period } \\
\cline { 2 - 3 } & CAGR & Instability & & CAGR & Instability & & CAGR & Instability \\
\hline Area & $2.12^{*}$ & 0.07 & & -0.10 & 0.07 & & 0.01 & 0.07 \\
Production & $6.00^{*}$ & 0.18 & & $3.59^{*}$ & 0.12 & & $3.97^{*}$ & 0.15 \\
Yield & $3.81^{*}$ & 0.16 & & $3.70^{*}$ & 0.09 & & $3.98^{*}$ & 0.12 \\
Export quantity & -2.75 & 0.72 & & $4.79^{*}$ & 0.34 & & $1.96^{*}$ & 0.55 \\
\hline
\end{tabular}

*Significant at 1 per cent level of significance Source: Computed using data from Spices Board

Table 2. Major sources of cardamom 1970 to 2017 (Production in tonnes)

\begin{tabular}{lcccc}
\hline Year & India & Guatemala & Indonesia & World Total \\
\hline TE 1970 & $3200(15.8)$ & $819(4.1)$ & $8925(44.1)$ & 20220 \\
TE 1980 & $6733(16.9)$ & $4494(11.3)$ & $18303(46.0)$ & 39798 \\
TE 1990 & $9733(18.9)$ & $11787(22.2)$ & $17598(33.1)$ & 53213 \\
TE 2000 & $13467(20.8)$ & $15424(23.8)$ & $19706(30.4)$ & 64895 \\
TE 2005 & $17233(21.3)$ & $30400(37.6)$ & $17214(21.3)$ & 80957 \\
TE 2010 & $15745(22.3)$ & $24480(34.7)$ & $17167(24.4)$ & 70487 \\
TE 2018 & $30000(26.2)$ & $34992(30.5)$ & $32670(28.5)$ & 114664 \\
\hline
\end{tabular}

Note: TE=Triennium Ending, Figures within the parentheses indicate percentage to total Source: Computed using data from FAOSTAT: http://www.fao.org/faostat/en/\#data 
Table 3. Trends in cardamom export from India

\begin{tabular}{|c|c|c|c|c|}
\hline Year & $\begin{array}{l}\text { Production } \\
\text { (Tonnes) } \\
\end{array}$ & $\begin{array}{c}\text { Quantity exported } \\
\text { (Tonnes) }\end{array}$ & $\begin{array}{c}\text { Share of exports } \\
\text { global exports } \\
(\%)\end{array}$ & $\begin{array}{l}\text { India's share in } \\
\text { in production } \\
(\%)\end{array}$ \\
\hline TE $1974-75$ & 3633 & 1685 & 46.3 & 48.6 \\
\hline TE $1984-85$ & 8600 & 1445 & 19.3 & 23.0 \\
\hline TE 1994-95 & 10247 & 1726 & 16.8 & 9.8 \\
\hline TE 2004-05 & 16333 & 1804 & 10.1 & 4.5 \\
\hline TE 2014-15 & 21345 & 4253 & 20.0 & 10.1 \\
\hline TE $2017-18$ & 24815 & 5535 & 22.3 & 8.7 \\
\hline
\end{tabular}

Source: Computed using data from Spices Board and UNCOMTRADE

decade. Guatemala produced 34992 tonnes of cardamom in Triennium Ending (TE) 2018. India is the third largest producer with a production of about 30000 tonnes in TE 2018. Indian cardamom commands a premium price in the international market due to its perceived quality parameters. The production and consumption of cardamom at the global level has shown a steady growth over the decades (Table 3 ). The highly concentrated production and trade of cardamom also underlines the chances for instability in supply and trade depending on the economic and agro-climatic scenario in the major production economies.

\section{Structural changes in Indian cardamom trade}

The disaggregated analysis of cardamom trade in terms of share in global exports, export partners and composition of exports provide insights on the structural and compositional changes that have occurred in the trade of this commodity. Historically, a significant share of cardamom produced in the country was exported. Nearly half of the domestic production was exported during the 1970's and India's share in global cardamom exports was also nearly $50 \%$. Since then, India's share in global cardamom exports has declined over the years. From a high share of $48.5 \%$ of the global cardamom exports during 1989-90, India's share in global cardamom exports has declined systematically and reached $8.7 \%$ during 2017-18. The export of cardamom as a share of domestic production has declined over the years mainly due to rising domestic demand for cardamom. The emergence of competing sources and enhanced production from other sources of supply at the international level has also contributed to the declining share in cardamom exports. For example, the cardamom production in Guatemala, which was around 800 tonnes during 1970 increased by nearly 20 times during the next three decades. With increasing competition at the global level and rising demand at the domestic level, Indian cardamom exports shrank considerably.

The share of domestic cardamom production exported, which touched a low of $10.1 \%$ during the TE $2004-05$ rose to $22.3 \%$ in $2017-18$ (Table 3 ). The cardamom exports from India have performed well only in those years when the cardamom crop output in Guatemala was affected by biotic or abiotic stress factors (Mishra et al. 2018). The trend in share of domestic production exported mirrors the trends in India's share in global trade. During the last few years, there is a perceptible revival in cardamom trade from the country. The revival reflects increased preference for cardamom from India in the global markets.

In nominal value terms, the export of cardamom and related products increased from Rs. 554 million in triennium ending 2000 to Rs. 6147 million in TE 2018. The exports in both processed and unprocessed cardamom products showed an increasing trend in value terms. The share of value added products in cardamom exports has also increased in the recent years. From $5.0 \%$ at the turn of the century, the share of value added products in cardamom exports has nearly tripled to 26.8 during the triennium ending 2018 (Table 4 ). The increased share of value added products in the export composition is a desirable feature. The better profit realization in the processed products of cardamom seems to have shifted the export composition in favour of value added products. The implicit value addition and 
Table 4. Export composition of cardamom exports from India (TE 2000 to TE 2018)

\begin{tabular}{cccc}
\hline Year & $\begin{array}{c}\text { Unprocessed products value } \\
\text { (Million INR) }\end{array}$ & $\begin{array}{c}\text { Processed products value } \\
\text { (Million INR) }\end{array}$ & $\begin{array}{c}\text { Total value } \\
\text { (Million INR) }\end{array}$ \\
\hline TE 2000 & $526.6(95.0)$ & $27.6(5.0)$ & 554.2 \\
TE 2003 & $483.9(92.9)$ & $37.2(7.1)$ & 521.1 \\
TE 2006 & $342.5(85.6)$ & $57.6(14.4)$ & 400.1 \\
TE 2009 & $915.6(87.1)$ & $135.4(12.9)$ & 1051.0 \\
TE 2012 & $2944.7(87.9)$ & $405.5(12.1)$ & 3350.2 \\
TE 2015 & $4010.1(79.3)$ & $1046.4(20.7)$ & 5056.4 \\
TE 2018 & $4501.0(73.2)$ & $1646.3(26.8)$ & 6147.4 \\
\hline
\end{tabular}

Note: 1. Figures within the parentheses indicate the percentage to total.

Source: Authors computation based on export composition data from export import data bank, Ministry of Commerce $\mathcal{E}$ Industry, Government of India

processing should benefit the stakeholders along the value chain through generation of additional employment.

\section{Comparative advantage in cardamom exports}

A country's ability to address the challenges in international market depends mainly on the export competitiveness of that country (Singh \& Sain 2003). While allowing for changes in relative abundance of production factors, the RCA reflects the changes in intrinsic export advantage of a particular commodity from a country. The Revealed Comparative Advantage

Table 5. Revealed Comparative Advantage (RCA) of cardamom in India

\begin{tabular}{lcc}
\hline Year & $\begin{array}{c}\text { Revealed } \\
\text { comparative } \\
\text { advantage }\end{array}$ & $\begin{array}{c}\text { Export unit } \\
\text { value } \\
\text { (US \$ per kg) }\end{array}$ \\
\hline $1988-90$ & 36.3 & - \\
$1991-95$ & 26.9 & 3.99 \\
$1996-00$ & 15.2 & 4.34 \\
$2001-05$ & 10.1 & 5.44 \\
$2006-10$ & 5.6 & 6.48 \\
$2011-15$ & 10.6 & 13.13 \\
$2017-18$ & 17.6 & 15.80
\end{tabular}

Source: Authors computation based on export composition data from export import data bank, Ministry of Commerce \& Industry, Government of India, WITS and UNCOMTRADE
(RCA) of Indian cardamom for various periods is presented in Table 5. While the above unitary value of RCA indicates the export competitiveness, there are significant changes in the RCA over the years. From the RCA it can be noted that India's competitiveness in cardamom exports was deteriorating gradually starting from the early 1990's until 2010. The unit export value of cardamom from India has consistently remained higher than that of the competing countries. Period of declining RCA for Indian cardamom also coincides with a spectacular rise in production from other major competing countries like Guatemala. Therefore, unless a supply shock occurs in the competing economies or the global demand significantly outpaces global supply, the Indian cardamom exports could remain less competitive than its competitors like Guatemala and Indonesia. The high input intensive production system of cardamom followed in major production tract like Idukki district of Kerala also raises the cost of production to an uncompetitive level.

Since 2010, the RCA value for Indian cardamom shows an improvement. The rising RCA could be attributed to the production and institutional constraints in Guatemala, the leading global cardamom exporter. Though the cardamom crop is a major export oriented crop in Guatemala, the research investment in the crop is poor and lack of adequate mechanisms for transfer of technology and monitoring of production has brought in significant challenges for the sustainability of the cardamom sector (Milian 
2014). The instabilities in Guatemala cardamom exports could have benefitted the Indian cardamom exports to enhance its competitiveness. The cardamom exports from Guatemala competes with Indian cardamom on the price front The overall cost of production of cardamom has also increased due to labour intensive nature of production and rising input cost (George \& Cherian 2017). The major cardamom producers and their volume of exports are presented in Table 6. India could further consolidate the gains in export competitiveness by reducing the cost of production through rationalization in use of plant protection chemicals, enhancing spread and adoption of crop management technologies, continued investment in research on crop protection technologies and promoting innovations in cardamom value chain. The cost of hired human labour constitutes about $47 \%$ of the paid out cost for small cardamom in Kerala, the leading producer in India (Government of Kerala 2016). The rationalization of labour input would require adoption of mechanization in cardamom cultivation and post-harvest handling.

Table 6. Top ten cardamom producers in the world and their exports- 2017

\begin{tabular}{|c|c|c|c|}
\hline \multirow[t]{2}{*}{ Country } & \multirow{2}{*}{$\begin{array}{l}\text { Production } \\
\text { (Tonnes) }\end{array}$} & \multicolumn{2}{|c|}{ Export } \\
\hline & & $\begin{array}{l}\text { Quantity } \\
\text { (Tonnes) }\end{array}$ & $\begin{array}{c}\text { Value } \\
\text { (‘000 US \$) }\end{array}$ \\
\hline Guatemala & 36259 & 35919 & 230104.39 \\
\hline Indonesia & 34385 & 4034 & 6112.40 \\
\hline India & 30000 & 5401 & 71192.11 \\
\hline Nepal & 6521 & 3025 & 36347.26 \\
\hline $\begin{array}{l}\text { Lao People's } \\
\text { Democratic } \\
\text { Republic }\end{array}$ & 3013 & 7.21 & 97.32 \\
\hline Grenada & 2775 & NA & NA \\
\hline Bhutan & 1086 & NA & NA \\
\hline $\begin{array}{l}\text { United Repu } \\
\text { of Tanzania }\end{array}$ & 738 & 0.05 & 0.002 \\
\hline Sri Lanka & 555 & 779.40 & 5789.13 \\
\hline Honduras & 490 & 741.43 & 2330.17 \\
\hline
\end{tabular}

Source: Production data from FAOSTAT; Export data from WITS

\section{Export destinations of cardamom from India}

Along with the changes in export competitiveness as measured by RCA, there has been considerable changes in the export destinations of cardamom exports from India. While some of the changes were occasioned by geopolitical factors, some changes reflect the regions of relative preference for cardamom of Indian origin. Saudi Arabia has emerged as the single largest importer of cardamom from India with a share of more than $50 \%$ since 2010 (Table 7 ). Five countries of the Middle East (Saudi Arabia, UAE, Iran, Kuwait and Qatar) are among the top ten export destinations for cardamom exports from India in 2016.

The preference for Indian cardamom in Saudi Arabia, which is the largest cardamom importer in the world is indicative of the willingness of the market to accept a premium price for the product from India. The destination analysis of the Indian cardamom exports clearly indicates that the product from India has gained a foothold in terms of consumer preference and value perception in the Middle East, which could significantly drive the export demand for cardamom from India. Along with the gains in market share in the Middle East economies, it is important for the sector to examine the reasons for the declining market share in Japan, where India's share has declined from $17.8 \%$ to less than $2 \%$ over a period of three decades.

Indian cardamom sector, which was the leading exporter of cardamom at the global level has witnessed a reversal in its role with the emergence of strong price based competitors like Guatemala and Indonesia. However, the increasingly robust domestic demand for the commodity and the higher domestic prices of cardamom in relation to the international prices strengthened the primary production sector. Though the area expansion in the crop was almost stagnant since the 1990's, the productivity growth remained significant even when the area expansion decelerated. Leveraging the strong growth in yield rates, the domestic output increased steadily during the past three decades. Along with the gains in yield realization, the diversification of export composition favouring value addition and the strong market preference for Indian cardamom in Middle East economies, 
Table 7. Changing pattern of India's cardamom export destination

\begin{tabular}{|c|c|c|c|c|c|c|c|}
\hline \multicolumn{2}{|c|}{1991} & \multicolumn{2}{|c|}{2001} & \multicolumn{2}{|c|}{2011} & \multicolumn{2}{|c|}{2016} \\
\hline Country & Share $(\%)$ & Country & Share $(\%)$ & Country & Share $(\%)$ & Country & Share $(\%)$ \\
\hline USSR & 35.5 & Saudi Arabia & 27.2 & Saudi Arabia & 50.0 & Saudi Arabia & 54.9 \\
\hline Japan & 17.8 & Japan & 15.9 & Pakistan & 13.5 & UAE & 12.7 \\
\hline Pakistan & 17.8 & Pakistan & 15.0 & UAE & 9.0 & Iran & 8.5 \\
\hline Saudi Arabia & 14.3 & UAE & 14.4 & Kuwait & 4.1 & USA & 3.6 \\
\hline UAE & 5.8 & Kuwait & 6.5 & U.K & 4.0 & Kuwait & 3.5 \\
\hline USA & 2.0 & Afghanistan & 1.7 & USA & 3.8 & UK & 2.6 \\
\hline U.K & 1.8 & Sweden & 1.7 & Malaysia & 2. & Japan & 1.9 \\
\hline Singapore & 1.0 & Greece & 1.6 & Oman & 1.6 & Pakistan & 1.9 \\
\hline Malaysia & 0.9 & U.K & 1.6 & Australia & 1.1 & Canada & 1.6 \\
\hline Kuwait & 0.5 & USA & 1.2 & Japan & 1.0 & Qatar & 1.5 \\
\hline
\end{tabular}

Source: WITS \& UNCOMTRADE

which is the major cardamom consuming region, has enhanced the export competitiveness of cardamom exports from India. The measured trends in RCA demonstrate this revival. The revival in export competitiveness, which had been steadily declining till the first decade of this century, augurs well for Indian cardamom sector. The revival is evident in share of domestic cardamom production being exported and in the slight increase in India's share in global cardamom exports.

The study also brings out the potential of the cardamom sector for enhancing its export performance through strong investments in research for enhancing efficiency of production. There is an urgent need to adopt latest technologies in spice processing and to strengthen product development in cardamom to exploit the trade potential in the crop (PIB 2019). The ability of the cardamom production sector in addressing critical challenges in food safety, sustainability and value chain efficiency will determine the ability of cardamom from India to corner world export markets for the commodity. Bringing in farm level traceability systems in value chains and promoting innovations in crop management technologies can systematically enhance the efficiency of the primary production sector. The impressive gains in productivity and output during the recent past can be transformed into income gains for the stakeholders along the value chain, only when the full benefits from the export markets can be tapped.

\section{Acknowledgments}

The authors acknowledge Director ICAR Indian Institute of Spices Research, Kozhikode for facilitating this study and the anonymous reviewers for their suggestions for improving the paper.

\section{References}

Anoopkumar M 2014 Intra-year price instability of commercial crops in India: Exploring the underlying dynamism. Int. J. Food Agrl. Econ. 2: $145-156$.

Balassa B 1965 Trade liberalisation and revealed comparative advantage, Manch. Sch. Econ. Soc. 33: 99-124.

Chand R \& Raju S S 2008 Instability in Andhra Pradesh Agriculture- A Disaggregate Analysis. Agric. Econ. Res. Rev. 21: 283-288.

FAOSTAT 2019 http://www.fao.org/faostat/en/ \#data

George M \& Cherian E 2017 Emergent global marketing challenges for Kerala cardamom producersvis-à-vis role of the spice board of India. Int. J. Community Dev. Manag. Stud. 1: 39-61.

Government of India 2014 Gazette of India Extraordinary Part II Section dated 3 
November 18, 2014 available at http:// www.indianspices.com/sites/default/files/ Cardamom\%20Licensing-ONE_1.pdf.

Government of Kerala 2016 Report on cost of cultivation of important crops in Kerala 201415. Department of Economics \& Statistics, Government of Kerala, 163p.

Mishra D P, Mishra S P \& Mishra N K 2018 The enhanced inland food chain and export disparities of small cardamoms in India: A critical review. Int. J. Res. Anal. Rev. 5: 448463.

Murugan M, Shetty P K, Ravi R, Subbiah A \& Hiremath M B 2011 Environmental impacts of intensive cardamom (small) cultivation in Indian cardamom hills: The need for sustainable and efficient practices. Recent Res. Sci. Technol. 3: 9-15.

Nagoor B H 2010 Trade Aspect of Plantation Sector of India. NRPPD discussion paper No.8. Centre for Development Studies, Thiruvananthapuram, 82p.

Nair P K P 2011 Agronomy and Economy of black pepper and cardamom: The "King" and "Queen" of spices. Elsevier Publications, 380p.

Nair P K P 2006 The Agronomy and Economy of Cardamom (Elettaria cardamomum M.): The "Queen of Spices". Adv. Agron. 91: 179-471.

Nair S K 2006 The problems of production and marketing in the cardamom industry with particular reference to Kerala. Unpublished Ph.D thesis, Department of Commerce and Management studies. University of Calicut, Kerala, 244p.
Press Information Bureau (PIB) 2019 Production, Export and Import of Cardamom. Press release dated 4 February 2019. Press Information Bureau, Ministry of Commerce and Industry, Government of India. Available at http://www.pib.nic.in/ Pressreleaseshare.aspx.

Shinoj P \& Mathur V C 2008 Comparative advantage of India in agricultural exports vis-á-vis Asia: A Post-reforms analysis. Agric. Econ. Res. Rev. 21: 60-66.

Singh K \& Sain I 2003 Prospects of Agricultural exports of India: A Composite Index Approach. Ind. J. Agric. Econ. 58: 781-799.

Spices Board 2015 Spice catalogue on small cardamom available at http:// www.indianspices.com/spice-catalog/ cardamom-small-1

Spices Board 2019 Spices Board of India. http:/ www.indianspices.com/statistics.

United Nations International Trade Statistics Database (UNCOMTRADE) 2019 https:// comtrade.un.org/data/

USDA 2014 Cardamom -The 3Gs - Green Gold of Guatemala, Global Agricultural Information Network Report Number: GT- 1404.United States Department of Agriculture (USDA) Foreign Agricultural Service, 8p.

Varghese P H 2007 Economics of Cardamom cultivation in Kerala Ind. J. Agric. Econ. 62: 99-112.

World Integrated Trade Solution (WITS) https:// wits.worldbank.org/ 